\title{
PULMONARY PARACOCCIDIOIDOMYCOSIS IN THE PNEUMOLOGY UNIT OF GENERAL HOSPITAL IN RECIFE (BRASIL). I。 ${ }^{1}$
}

\author{
Paracoccidioidomicosis pulmonar en la unidad de neumología de un \\ hospital general en Recife (Brasil).I.
}

\author{
Oliane,M.C. Magallhaes, ${ }^{*}$ Lusinete, A.de Queiroz, * \\ Cristina, M. de Souza*, Laura, Torres.** \\ *Departamento de Micología, Centro de Ciências Biol., \\ Universidade Federal de Pernambuco, 50670-420, Recife, PE, Brasil \\ ** Hospital Geral Otavio de Freitas(SANCHO), Recife,PE, Brasil.
}

Palabras clave: Faracoccidioidomicosis pulmonar Key words: Pulmonary paracoccidioidomycosis

\section{SUMMARY}

In order to determine the presence of fungi in clinical samples of the respiratory system, 322 patients with pneumopathies were surveyed. All of them had been hospitalised in the Pneumology Unit of the Otavio de Freitas General Hospital, Recife, PE, Brazil. Paracoccidioidomycosis was diagnosed in 7 male patients $(2.1 \%)$, and involved with work in the rural zone. In 6 cases there was a "diagnostic mistake" between pulmonary tuberculosis and pulmonary paracoccidioidomycosis; in 1 case the association of these two pneumopathies was verified.

\section{INTRODUCTION}

Fungal pneumo pathies present clinical aspects wue.. may be suggestive of other pulmonary diseases, mainly pulmonary tuberculosis (PT) (Hendrix et al., 1992; Peres et al.,1992; Stanley et al., 1992). Many papers havefocussed on the difficulties in the diagnostic differential between fungal pneumopathiesand otherdiseases, by highlight PT (Berkowitz \& Diamond, 1987), occurrences of the two pneumopathies simultaneously (Morozovetal., 1989), as well as the unleashing of the post PT fungal pneumopathy ( Al-Majed et al., 1990).

Among the pulmonary mycoses, pulmonary paracoccidioidomycosis (PP) may be associated with PT (Rippon, 1982; Wanke, 1984; Tuder et al.,1985; Ferreira-daCruz et al., 1987; Lacaz et al.,1991). On the other hand, due to the difficulties in differential diagnosis between these two pneumopathies, "diagnostic mistake" may occur between the

\section{RESUMEN}

Para determinar la presencia de hongosen muestras clínicas de vias respiratorias, fueron pesquisados 322 pacientes con pneumopatias internos en la unidad de neumologia del Hospital General Otavio de Freitas, Recife, PE, Brasil. Se diagnosticaron 7 casos de paracoccidioidomicosis $(2,1 \%)$, todos del sexo masculino y relacionados a trabajos rurales. En 6 casos se constató " diagnostico errado" entre tuberculosis pulmonar y Paracocidioidomicosis pulmonar; en 1 caso fue comprobada la asociación de estas 2 neumopatías.

two of them(Londero \& Severo, 1981;Rippon, 1982; Wanke, 1984; Lacaz et al.,1991).

Paracoccidioidomycosis $(\mathrm{P})$ is caused by the dimorphic fungus Paracoccidioides brasiliensis (Splendore) Almeida. In Brasil it is the most frequent systemic mycosis, specially in the SouthEast, South and Centre-West, with less incidence in the Northeast and rarely in Amazonia (Wanke, 1984). The objectives of this papers were detect, isolate and identify fungi of the respiratory system of patients hospitalised in the Pneumology Unit of the Otavio de Freitas General Hospital, Recife, PE, Brasil; to determine the existence of fungal pneumopathy; to verify the association of this pneumopathy with other pathologies of the respiratory system.

\section{MATERIAL AND METHODS}

Clinical samples were collected from patients with problems in the respiratory system who had been hospitali- 
zed in mentioned institution. In 322 patient surveyed, 225 were males and 97 females. From each patient who had not been drained and wasfasting, sputum sampleswere collected 3 times at intervals of 3 to 4 days in sterilized Petri dishes; samples of secretions of the lesions from buccal (cheek and gums) mucosa were also collected from one patient and transferred by physiological drip contained in a test tube. After collection, the clinical samples were transported to the Department of Mycology where they were duly processed for direct examination and culture. The time between collection and manipulation of the samples dit not exceed 2 hours. The direct examination both of the sputum and the secretions of lesions frombuccal mucosa wasundertaken in the native state (without colouring and without clarifier), and clarified with aqueous solution with $20 \%$ potassium hydroxide.

In duplicate, the clinical samples were seeded by spreading on their surface agar infusion of brain and heart (BHIDifco) and with Sabouraud agar $+0,5 \%$ of yeast extract (YE), to both of which $50 \mathrm{mg}$ of Caf./1 were added. A plate of each method was left at room temperature $\left(\mathrm{RT} 28^{\circ} \mathrm{C}\right.$ approx.) and the other at $37^{\circ} \mathrm{C}$. Culture plates were incubated for 3 weeks. The pure culture obtained were maintained in BHI agar and Sabouraud $+0.5 \%$ of YE and at RT. The identification of $\boldsymbol{P}$. brasiliensis was confirmed through Conant et al., 1971; Rippon, 1982; Lacaz et al., 1991.

\section{RESULTS AND DISCUSSION}

PP was diagnosed through the direct examination of sputum of 7(2.1\%) patients (Table 1). Only one of these was a bearer of lesions in the buccal mucosa and the direct examination of the secretion of the latter also revealed the presence of $\boldsymbol{P}$. brasiliensis. The direct examination of sputum and secretion revealed the presence of yeast-like cells with double contour, single and multiple budding, resulting in "Mickey mouse" formations, in a chain and in helm shape, characteristic of parasitic phase of $\boldsymbol{P}$. brasiliensis (Figures 1 to 7 ).

In BHI+Caf. cultures, $\boldsymbol{P}$.brasiliensis were obtained for 3 patients (Table 1). The strains were deposited in the Micoteca-URM, of the Mycology Department ,Centre of Biol. Sc, Federal Univ. of Pernambuco, under $N^{\circ} 3633,3634$, 3635.

All the cases of PP were diagnosed in male patients, with a minimum age of 17 and a maximum of 76 years, the majority of cases being between the ages of 31 and 48 . Among the 7 patients, 6 were from the rural zone of the State of Pernambuco, and engaged in rural work; only one patient was a native of the State of Alagoas and although he had been a resident of the city of Recife for 20 years working as a watchman, he had once been a rural worker (Table .1)

These results agree with those previously reported in the literature according to which the rural worker over 30 years old is the representative of the majority of the reports of $\mathrm{P}$; however there are reports of the afores aid mycosis in individuals who have never undertaken rural work (Conant etal., 1971;Rippon, 1982; Wanke, 1984; Lacaz et al.,1991)

The 7 patiens with PP had been previously treated has having PT, 1 with positive BAAR (Bacilo-alcohol-acid resistant), 5 with negative BAAR and 1 without BAAR having been undertaken (Table 1). In 6 of these cases it was verified that the pneumopathy was PP and only 1 case was the association confirmed between the 2 pneumopathies,PP and PT. Among the 6 patients uniquely with PP, only 1 was also a carrier of diabetes mellitus (Table 1).

The association of PP and PT has been reported by various authors (Rippon, 1982; Wanke, 1984; Tuder et al. 1985; Ferreira-da-Cruz et al., 1987; Lacaz et al., 1991).

According to Wanke (1984), PP may be associated with PT as well as with neoplasias, reflecting immunological compromise which accompaniesthe disease.

Clinical and radiological examinations do not help much in the diagnosis of PP, because they may suggest diagnoses for other pneumopathies, such as tuberculosis and neoplasia. As a result of this, many patients are treated as if they were bearers of PT even without laboratory confirmation (negative BAAR) (Wanke, 1984; Lacazetal., 1991). The mycological examination detecting P.brasiliensis, in all cases of PP, only took place some months after treatment for PT without clinical and radiological inmprovement, thus indicating "diagnostic mistake". This same type of " diagnostic" has already been reported in the literature (Londero \& Severo, 1981;Rippon, 1982; Wanke, 1984; Lacazet al., 1991).

"Diagnostic mistake" has also been taking place be tween PT and other mycoses such as: blastomycosis, penicilosis, coccidioidomycosis, cryptococosis and aspergillosis (Frean et al.,1983; Berkowitz \& Diamond, 1987; Pautler et al.,1984; Forsbach etal.,1985; Shang \& Song, 1987; Hendrix etal.,1992).

The ocurrence of a case of $\mathrm{P}$ in the State of Pernambuco, Northeast of Brasil was reported by Guimaraeset al.(1985); since then personal communication by professionals in the Health field has indicated various cases of this mycosis in the same State. On theother hand, Carneiro(1993), found $20 \%$ of positiveness for paracoccidioidine in school children of Greater Recife, these results indicate the contact of these childrenshave with $\boldsymbol{P}$. brasiliensis, and suggest the possible occurrence of this illness in Recife's inhabitants.

So we can concluded tha t no case of PP associated with another mycosis has been found; PP, occurred in an isolated manner in most cases; PP may be associated with PT; there may be "diagnostic mistake" between PP and PT. The direct examination of the sputum was conclusive for diagnosing PP. 

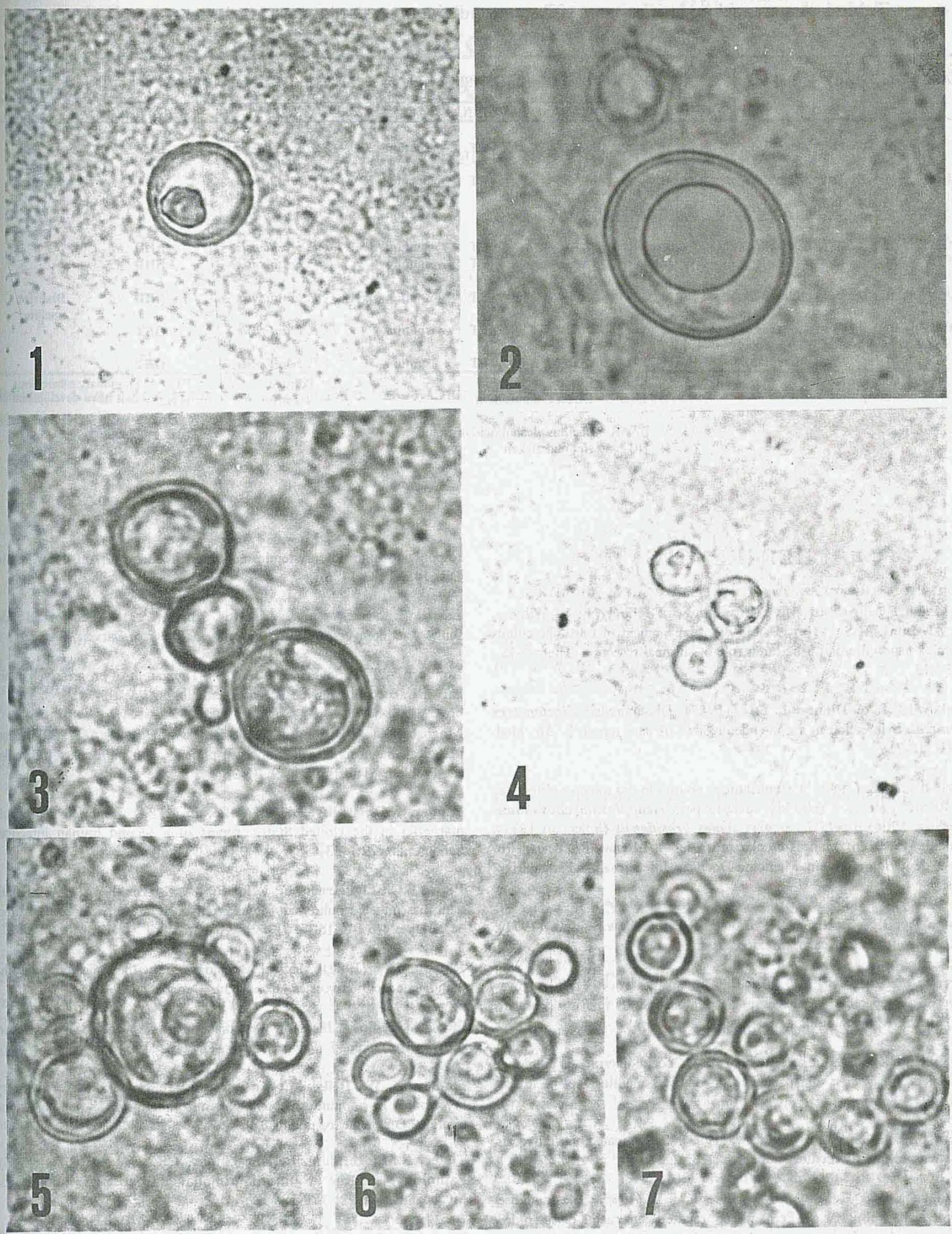

Fig. 1 to 7. - Paracoccidioides brasiliensis in the sputum. 1-2.-Cells with double refractary contour, without budding 960x, 1360x. 3-4.-Cells with double refractary contour, and single budding, 1360x, 650x.5-6-7.-Cells with double refractary contour, and multiplebudding, $1360 \mathrm{x}$. 
Table 1. Aspects related to the cases of Paracoccidioidomycosis diagnosed in patients hospitalized

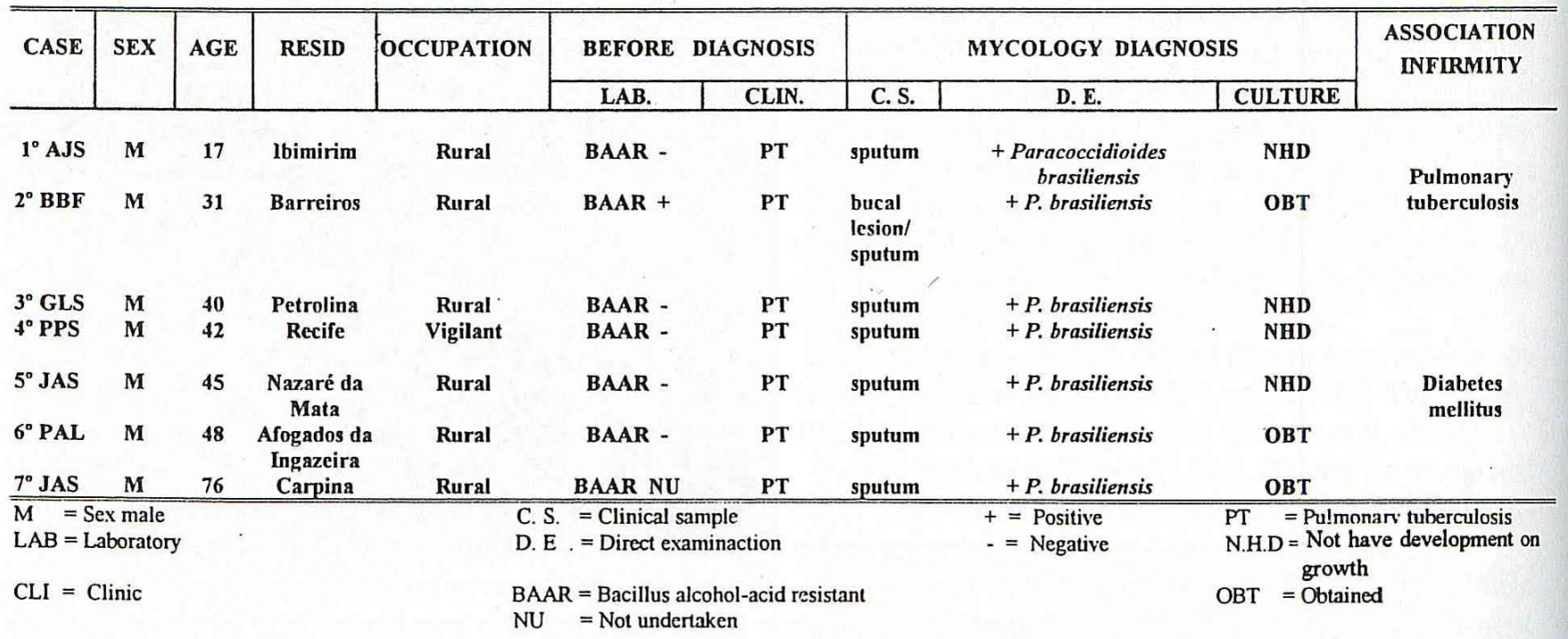

\section{REFERENCES}

Al-Majed, S.A.; Ashour, M.; El-Kassim, F.A.; Joharjy, I.; A1-Wazzan, A.; Al-Hajaj, M.S.; Vijay, R. (1990). Management of post-tuberculous complex aspergilloma of the lung: role of surgical resection. Thorax, 45 : 846-849

Berkowitz, I. \& Diamond, T.H. (1987). Disseminated Blastomyces dermatitidis infection in a non-endemic area. A case report. S. Afr. Med. J. $71: 718-719$

Carneiro, R.M. (1993 ). Contribuiçao ao estudo das micoses sistêmicas no Recife. Fatores e risco da infecçao pelo Histoplasma capsulatum (Darling, 1906) e pelo Paracoccidioides brasiliensis (Splendore,1912). Almeida, 1930, em crianças escolarizadas de 7 a 14 anos. Rio de Janeiro, (Tese de Doutorado em Medicina-Doenças Infecciosas e ParasitáriasUFRJ)

Connant, N.F.; Smith, D.T.; Baker, R.D.; Callaway, J.L. (1971). Micologia, Interamericana, México

Ferreira-da-Cruz, M.F.; Wanke, B.; Galvao-Castro, B. (1987). Prevalence of paracoccidioidomycosis in hospitalized adults in Rio de Janeiro (RJ) Brasil. Mycopathologia 97: 61-64

Forsbach, G.B.S. \& Fuentes, R.P. (1985). Coccidioidomicosis pulmonar crónica progresiva en una paciente con diabetes mellitus type I. Invest. Clin. 37: 49-51

Frean, J.; Blumberg, L.; Woolf, M. (1993). Disseminated blastomycosis masquerading as tuberculosis. J. Infect. 26: 203-206

Guimaraes, M.; Campos, G.S.; Pessoa, F.P. (1985). Blastomicose sulamericana pulmonar em Pernambuco: relato de um caso e discurso dos aspectos epidemiológicos e diagnósticos. J. Pneumol. 11: 149-151

Hendrix, W.C.; Arruda, L.K.; Platts, M.T.A.; Haworth, C.S.; Jabour, R.; Ward, G.W.Jr. (1992). Aspergillus epidural abscess and cord compression in a patient with aspergilloma and empyema. Survival and response to high dese systemic amphotericin therapy. Am. Rev. Respir. Dis. 145: $1483-1486$

Lacaz, C. da S.; Porto, E.; Martins, J.E.C. (1991). Micologia Médica: fungos, actinomycetes e algas de interesse médico. Sarvier, Sao Pablo

Londero, A.T. \& Severo, L.C. (1981). The gamut of progressive pulmonary paracoccidioidomycosis. Mycopathologia. 75: 65-74

Morozov, V.; Al-Dzhambaeva-I, S.H.; Dambekov, D.A. (1989). Immunological diagnosis of aspergilosis in patients with pulmonary tuberculosis. Problemy Tuberkuleza 9: 35-38

Pautler, K.B.; Padhye, A.A.; Ajello, L. (1984). Imported penicillosis marneffei in the United States: report of a second human infection. Sabourandia 22: $433-438$

Peres, L.C.; Figueiredo, F.; Peinado, M.; Soares, F.A. (1992). Fulminant disseminated pulmonary adiaspiromycosis in humans. Am. J. Trop. Med. Hyg. 46: 146-150

Rippon, J.W. (1982). Medical Mycology: the pathogenic fungi and the pathogenic actinomycestes. Copyright, Canada

Shang, J. \& Song, H. (1987). Primary pulmonary cryptocococis: report of two cases. Chin. J. Tuberc. Respir. Dis. 10: 89-91

Stanley, M. W.; Deike, M.; Knoedler, J.; Iber, C. (1992). Pulmonary mycetomas in immunocompetent patients: diagnosis by fine-needle aspiration. Diaqn. Cytopathol. 8: 577-579

Tuder, R.M.; Ibrahim, R. E1.; Godoy, C.E.; De Brito, T. (1985). Pathology of the human pulmonar paracoccidioidomycosis. Mycopathologia 92: 179-188

Wanke, B. (1984). Micoses pulmonares. Ars. Curandi .pp. 71-85 